\title{
ANALISIS POTENSI ASSET DAERAH SEBAGAI SUMBER PENDAPATAN ASLI DAERAH DI KOTA JAYAPURA
}

(Studi Kasus Potensi Pasar dan Terminal)

\author{
Transna Putra Urip $\mathbf{S}^{1}$ \\ transnaputra@yahoo.co.id
}

\begin{abstract}
The purposes of this research were to analyse potentialities of local markets and public transportations terminals as Local-Generated Revenue Sources and the effectiveness and efforts to optimise Local-Generated Revenues. This research was conducted in Jayapura Municipality.

The research variables were facilities in the markets and terminals, terminal levy, payments frequency, and actual revenue from the markets and terminals. A quantitative approach was employed using potentials components and effectiveness ratios which later being analyse descriptively.

The study showed an increase of propensity in the markets' actual growth of revenues in an average of $11.97 \%$ and trends of the terminals' levies growth in an average of $-11.70 \%$. The potential revenues from terminals' levy were 4.088.502.000 IDR and 1.312.488.000 IDR. Thus, the total potential revenue was 5.400.990.000 IDR. The effectiveness level of actual revenues from markets fees reached 19.30 per cent and the actual terminals levies was 18.64 per cent. Hence, the total effectiveness level of markets and terminals fees was 19.18 per cent. Efforts were the improvements of local officers' qualities, systems, administrations and working procedures, the corrective planning of local markets and terminals as well as assertive actions. Legal efforts were necessary to shed light on land ownerships to the local markets.
\end{abstract}

Keywords: Levy, Markets, Terminals, Potential, Effectiveness, Facilities, Tariff

\section{PENDAHULUAN}

Pelaksanaan otonomi daerah sebagaimana diatur dalam Undang-undang No. 32 Tahun 2004 tentang Pemerintahan Daerah yang menyatakan pemberian otonomi daerah kepada daerah atas dasar desentralisasi yakni tersedianya sumber-sumber pembiayaan dalam wujud otonomi otonomi yang luas, nyata dan bertanggungjawab. Dalam pelaksanaan otonomi daerah, pemerintahan daerah dalam implementasi

\footnotetext{
1 Staf Pengajar Pada Jurusan IImu Ekonomi Fakultas Ekonomi Universitas Cenderawasih
} 
kebijakan pengelolaan barang milik daerah merupakan komponen penting dalam penyelenggaraan kegiatan pengelolaan keuangan daerah. Oleh karena itu pengelolaan aset daerah perlu melakukan pengorganisasian yang baik. Salah satu peraturan yang menjadi dasar terhadap pengelolaan aset daerah pada Pemerintah Daerah Kota Jayapura adalah disamping Undang-undang No. 6 Tahun 2006 tentang Pengelolaan Barang Milik Negara/Daerah, Peraturan Menteri Keuangan No. 120/PMK.06/2007 tentang Penatausahaan Barang Milik Negara dan Peraturan Menteri Keuangan No. 96/PMK.06/2007 tentang Tata Cara Pelaksanaan Penggunaan, Pemanfaatan, Penghapusan dan Pemindahtanganan Barang Milik Negara juga berdasarkan Peraturan Pemerintah No. 6 Tahun 2006 Tahun 2006 dan Peraturan Daerah (PERDA) Pemerintah Daerah Kota Jayapura No. 4 tahun 2006 tentang pengelolaan Barang Milik Daerah Pemerintah Kota Jayapura. Sebagai tambahan khusus untuk pengelolaan barang milik daerah (BMD) telah dikeluarkannya Peraturan Menteri Dalam Negeri No. 17 Tahun 2007 tentang Pedoman Teknis Pengelolaan Barang Milik Daerah. Dimana Permendagri tersebut dikeluarkan untuk melaksanakan ketentuan pasal 74 Ayat (3), PP No. 6 Tahun 2006 yang berbunyi : " Menteri Dalam Negeri Menetapkan kebijakan teknis dan melakukan pembinaan pengelolaan barang milik daerah sesuai dengan kebijakan sebagaimana ayat (!) " Menurut Ketentuan Pasal 2 Permendagri tersebut Pengelolaan barang milik daerah merupakan bagian dari pengelolaan keuangan daerah yang dilaksanakan secara terpisah dari pengelolaan barang milik negara.

Kota Jayapura merupakan pusat kegiatan ekonomi, pendidikan dan sentral Pemerinta Propinsi Papua. Dalam Pengelolaan aset merupakan bagian yang tidak terpisahkan dari manajemen/pengelolaan keuangan dan secara umum terkait dengan administrasi pembangunan daerah khususnya yang berkaitan dengan nilai aset, pemanfaat aset, pencatatan nilai aset dalam neraca, maupun dalam penyusunan 
prioritas dalam pembangunan. Sedangkan pengelolaan aset kedepan lebih ditujukan untuk menjamin pengembangan kapasitas yang berkelanjutan dari pemerintah daerah, maka dituntut agar dapat mengembangkan atau mengoptimalkan pemanfaatan aset daerah guna meningkatkan/mendongkrak pendapatan asli daerah, yang akan digunakan untuk membiayai kegiatan guna mencapai pemenuhan persyaratan optimal bagi pelayanan tugas dan fungsi instansinya terhadap masyarakat. Aset atau barang daerah merupakan potensi ekonomi yang dimiliki oleh daerah. Potensi ekonomi bermakna adanya manfaat finansial dan ekonomi yang bisa diperoleh pada masa yang akan datang, yang bisa menunjang peran dan fungsi pemerintah daerah sebagai pemberi pelayanan publik kepada masyarakat. Adapun Aset daerah diperoleh dari dua sumber yakni aset yang bersumber dari pelaksanaan APBD yang mana merupakan output/outcome dari terealisasinya belanja modal dalam satu tahun anggaran, dan kedua adalah aset yang bersumber dari luar pelaksanaan APBD yang mana dalam hal ini perolehan aset tidak dikarenakan adanya realisasi anggaran daerah baik anggaran belanja modal maupun belanja pegawai serta belanja barang dan jasa.

Pengelolaan aset daerah merupakan salah satu kunci dari keberhasilan pengelolaan ekonomi daerah. Pentingnya pengelolaan aset secara tepat dan berdayaguna dengan didasari prinsip pengelolaan yang efisien dan efektif, diharapkan dapat meningkatkan sumber pendapatan asli daerah (PAD) .

Beberapa aset daerah di Kota Jayapura yang dapat menjadi sumber pendapatan asli daerah, dimana pendapatan ini berasalah dari retribusi daerah. Perkembangan retribusi daerah kota jayapura menunjukkan peningkatan dimana pada tahun 2009 sebesar Rp.18.062.660.000,- dan meningkat menjadi Rp.30.189.52.000,- pada tahun 2013. Diantaranya aset daerah yang memberikan kontribusi dalam pembentukan retribusi daerah adalah pasar dan terminal. 
Perkembangan realisasi retribusi pasar menunjukkan kecenderungan yang meningkat walupun pada tahun tertentu terjadi penuruan, diman pada tahun 2009 penerimaan retribusi pasar sebesar Rp. 366.867.700,dan pada tahun 2013 tekah meningkat menjadi Rp.788.927.500,-. Namun pada tahun 2011 terjadi penurunan retribusi menjadi Rp. 249.746.500,- kondisi ini tentunya memberikan gambaran adanya ketidak konsistenan penerimaan retribusi pasar. Jika dibandingkan dengan pertumbuhan ekonomi tahun 2010 sebesar 20,42 tentunya penuruanan ini menjadi fenomena yang perlu pelajari lebih jauh.

Perkembangan realisasi retribusi terminal cenderung yang sangat fluktuatif dan menurun, dimana pada tahun $2009 \mathrm{Rp}$. 450.505.000,- dan pada tahun 2013 menurun menjadi Rp 244.706.000,-. Fenomena ini tentunya bertolak belakang dengan perkembangan retribusi daerah dan pertumbuhan ekonomi yang terjadi. Berbagai kondisi perkembangan retribusi daerah, retribusi pasar dan terminal serta pertumbuhan ekonomi menunjukkan ketidakserasian perkembangannya. Hal ini tentunya menjadi fenomena yang perlu dilihat lebih dalam untuk mengetahui kondisi yang perlu untuk di cari solusinya. Berdasarkan latarbelakang di atas, maka rumusan masalah akan dirinci ke dalam beberapa pertanyaan penelitian berikut ini : 1) Bagaimana Potensi Penerimaan Retribusi Pasar dan Retribusi Terminal di Kota Jayapura? 2) Bagaimana Efektivitas penerimaan Retribusi Pasar dan Retribusi Terminal di Kota Jayapura? 3) Bagaimana Upaya-upaya yang dilakukan guna meningkatkan penerimaan Retribusi Pasar dan Retribusi Terminal di Kota Jayapura? Karena banyaknya asset daerah dari pemerintah Kota Jayapura, dan agar penelitian ini dapat dilakukan dengan lebih baik maka perlu dilakukan pembatasan terhadap masalah yang akan dibahas, dimana penelitian ini hanya menitikberatkan pembahasan terhadap Aset daerah dalam bentuk Bangunan yang dalam hal ini adalah : 1) Bangunan Terminal. 2) Bangunan Pasar. Adaun kegunaan dari studi ini yaitu untuk mengkaji dan menganaisis 1) 
Potensi Penerimaan Retribusi Pasar dan Retribusi Terminal, 2) Efektivitas penerimaan Retribusi Pasar dan Retribusi Terminal di Kota Jayapura dan 3) Upaya-upaya yang dilakukan guna meningkatkan penerimaan Retribusi Pasar dan Retribusi Terminal di Kota Jayapura.

\section{METODE PENELITIAN}

\section{Lokasi Penelitian}

Penelitian ini dilakukan pada Pemerintah Kota Jayapura menggunakan data yang dikeluarkan oleh Bappeda, BPKAD dan Dispenda Kota Jayapura, Terminal Youtefa, Pasar Youtefa, Pasar Hamadi dan Pasar Inpres Dok IX.

\section{Jenis dan Sumber Data}

Jenis dan sumber data yang digunakan untuk membahas penelitian ini adalah sebagai berikut :

a. Jenis Data

Data dalam penelitian ini merupakan data kuantitatif yaitu data dalam bentuk angka. Adapun data kuantitatif yang akan digunakan dalam penelitian ini adalah data penerimaan retribusi pasar, retribusi terminal, jumlah kios, jumlah los dan pelataran, frekuensi keluar masuk kendaraan angkutan umum penumpang di terminal.

b. Sumber Data

Dilihat dari sisi sumber data maka data dalam penelitian ini adalah data primer dan data sekunder, dimana: data primer yang diperlukan diperoleh melalui wawancara denganKepala Pasar, Kepala Terminal, sedangkan data sekunder yang diperlukan akan diperoleh melalui kantor Bappeda, BPKAD, Perindagkop Dan Dispenda Kota Jayapura. Dokumen yang diperlukan adalah Realisai anggara, laporan tahunan dispenda tentang pendapatan daerah, laporan Kepala Pasar dan Terminal. 


\section{Metode Pengumpulan Data}

Studi Dokumentasi Suatu cara pengumpulan data sekunder dengan mengambil data dari instansi-instansi yang terkait. Data yang diperoleh dalam teknik ini adalah data kondisi umum yang tercatat dalam publikasi pemerintah yang berhubungan dengan tujuan penelitian.

\section{Metode Analisis}

Adapun metode analisis yang digunakan dalam penelitian ini sekaligus merupakan alat analisis adalah sebagai berikut:

a. Untuk menjawab masalah pertama tentang Potensi penerimaan Retribusi Pasar dan Retribusi Terminal akan digunakan formula sebagai berikut:

1) Pasar

$$
R_{p s r}=\left(K \times T_{k} \times F_{k}\right)+\left(L \times T_{1} \times F_{l}\right)+\left(P I t \times T_{p l t} \times F_{p l t}\right)
$$

Keterangan :

$\mathrm{R}_{\mathrm{psr}} \quad=$ Penerimaan Retribusi Pasar

$\mathrm{K}=$ Jumlah Kios

$\mathrm{T}_{\mathrm{k}} \quad=$ Tarif Kios

$\mathrm{F}_{\mathrm{k}} \quad=$ Frekuensi Pembayaran Kios

$\mathrm{L}=$ Jumlah Los

$\mathrm{T}_{1} \quad=$ Tarif Los

$\mathrm{F}_{\mathrm{I}} \quad=$ Frekuensi Pembayaran Los

PIt = Jumlah pengguna pelataran

$\mathrm{T}_{\text {plt }}=$ Tarif pelataran

$\mathrm{F}_{\mathrm{plt}} \quad=$ Frekuensi Pembayaran Pelataran

2) Terminal

$R t=(K t \times F m x T k)$

Keterangan :

Rt $=$ Penerimaan Retribusi Terminal

$\mathrm{Kt}=$ Jumlah Kendaraan Masuk Terminal

$\mathrm{Ft}=$ frekuensi Masuk Terminal per kendaraan

$\mathrm{Tt}=$ Tarif Masuk Terminal 
b. Untuk menjawab masalah kedua tentang Efektifitas penerimaan Retribusi Pasar dan retribusi Terminal akan dianalisi dengan menggunakan rasio efektifitas, dimana yang akan dilihat adalah perbandingan antara realisasi penerimaan retribusi dengan Potensi retribusinya. Adapun formula yang digunakan adalah :

$$
E p t_{t}=\frac{R_{p t}}{P_{p t}} \times 100 \% \quad(\text { Widodo : 1990, 22) }
$$

Dimana :

$$
\begin{aligned}
\mathrm{E}_{\mathrm{pt}} \quad & \text { efektifitas penerimaan Retribusi Pasar atau } \\
& \text { Retribusi Terminal } \\
\mathrm{R}_{\mathrm{pt}} & \begin{array}{l}
\text { jumlah Realisasi penerimaan Retribusi Pasar } \\
\end{array} \\
& \text { atau Retribusi Terminal } \\
\mathrm{P}_{\mathrm{pt}} & \text { jumlah Potensi penerimaan Retribusi Pasar } \\
& \text { atau Retribusi Terminal }
\end{aligned}
$$

Adapun kriteria efektifitas akan dikgunakan kriteria yang dikemukakan oleh Abdul Halim dan M. Iqbal (2012) sebagai berikut:

Tabel 1.

Kriteria Efektifitas

\begin{tabular}{|c|c|}
\hline Nilai & Efektifitas \\
\hline$>100 \%$ & Sangat Efektif \\
\hline $76 \%-100 \%$ & Efektif \\
\hline $51 \%-75 \%$ & Kurang Efektif \\
\hline $26 \%-50 \%$ & Tidak Efektif \\
\hline $0 \%-25 \%$ & Sangat Tidak Efektif \\
\hline
\end{tabular}

Sumber: Abdul Halim, M. Iqbal 2012

c. Untuk menjawab masalah ketiga tentang upaya-upaya optimalisasi penerimaan penerimaan Retribusi Pasar dan Retribusi Terminal dari Pejabat Perindagkop dan Dispenda akan 
dilakukan dengan mendeskripsikan berbagai hambatan dan upaya melalui analisis deskriptif kualitatif.

\section{Definisi Operasional}

a. Retribusi Pasar adalah semua pendapatan daerah yang berasal dari pungutan retribusi pelayanan pasar terhadap penggunaan fasilitas pasar oleh para pedagang. dimana satuannya adalah rupiah

b. Retribusi terminal adalah semua pendapatan daerah yang berasal dari pungutan terhadap penggunaan fasilitas terminal oleh kendaraan angkutan umum penumpang yang masuk ke dalam terminal dimana satuannya adalah rupiah

c. Efektifitas Penerimaan Retribusi adalah perbandingan antara nilai realisasi penerimaan retribusi dan potensi penerimaan retribusi dimana satuannya adalah \% (persen)

\section{HASIL DAN PEMBAHASAN}

1. Potensi Penerimaan Retribusi Pasar dan Terminal di Kota Jayapura

Potensi penerimaan PAD dari Retribusi Pasar dan Terminal di Kota jayapura terbagi menjadi dua bagian besar yaitu potensi retribusi pelayanan pasar dan potensi retribusi terminal.

\section{Potensi Retribusi Pelayanan Pasar}

Retribusi Pelayanan Pasar merupakan jenis retribusi yang masuk dalam kelompok retribusi jasa umum dan berdasarkan Peraturan Daerah Kota Jayapura Nomor 2 tahun 2012 tentang Retribusi Jasa Umum Bab VIII tentang Retribusi Pelayanan Pasar maka setiap penggunaan fasilitas pasar dalam hal ini Kios, Los dan Pelataran dikenakan pungutan retribusi. Berdasarkan regulasi inilah 
maka aset daerah dalam bentuk pasar merupakan salah satu sumber penerimaan PAD.

a. Potensi Retribusi dari Kios

Adapun tarif yang dikenakan untuk Pasar Kelas II untuk fasilitas Kios permanen $1 \mathrm{~m} \times 1 \mathrm{~m}=$ Rp. $500 /$ hari, karena rata-rata kios ukuran $3 \mathrm{~m}$ x 6 m maka Kios dikenakan Rp. 9000/hari $(3$ x 6 x $500=9000)$.

Tabel 2.

Potensi Retribusi Pelayanan Pasar dari Fasilitas Kios dalam satu tahun di Kota Jayapura Tahun 2014

\begin{tabular}{|c|c|c|c|c|}
\hline Pasar & $\begin{array}{c}\text { Jumlah } \\
\text { Kios }\end{array}$ & $\begin{array}{l}\text { Tarif } \\
\text { (Rp) }\end{array}$ & $\begin{array}{c}\text { Frekuensi } \\
\text { Bayar }\end{array}$ & $\begin{array}{c}\text { Jumlah } \\
\text { (Rp) }\end{array}$ \\
\hline Youtefa & 524 & 9,000 & 360 & $1,697,760,000$ \\
\hline Hamadi & 375 & 9,000 & 360 & $1,215,000,000$ \\
\hline Tanjung Ria Dok IX & 83 & 9,000 & 360 & $268,920,000$ \\
\hline Jumlah & 982 & & & $3,181,680,000$ \\
\hline
\end{tabular}

Sumber : data diolah tahun 2014

Berdasarkan hasil analisis potensi diketahui bahwa untuk Pasar Youtefa potensi penerimaan retribusi berdasarkan fasilitas kios diperoleh nilai sebesar Rp. 1.697.760.000,- . yang berasal dari 524 kios yang ada. Untuk Pasar Hamadi potensi penerimaan dari faslitas Kios sebanyak 375 unit besarnya adalah Rp. 1.215.000.000,- . Untuk Pasar Tanjung Ria Dok IX dari 83 unit kios maka potensi penerimaannnhya adalah Rp. 268.920.000,-. Dengan demikian potensi penerimaan retribusi pelayanan pasar dari fasilitas kios di Kota Jayapura adalah Rp. 3.181.680.000,- dalam satu tahun. Kondisi ini dapat diperoleh apabila aktivitas pasar dapat berjalan dengan maksimal dan pemungutannya juga dilakukan dengan maksimal.

b. Potensi Retribusi dari Los 
Adapun tarif yang dikenakan untuk Pasar Kelas II untuk fasilitas Los $1 \mathrm{~m} \times 1 \mathrm{~m}=$ Rp. 725/hari, berdasarkan pengamatan mmang terlihat ada Los yng digunakan lebih luas dari $1 \mathrm{~m} \times 1 \mathrm{~m}$, namun dalam perhitungan potensi akan dihitung sesuai perda no. 2 . tahun 2012 tentang retribusi jasa umum.

Tabel.3.

Potensi Retribusi Pelayanan Pasar di dari Fasilitas Los Kota Jayapura Tahun 2014

\begin{tabular}{|l|c|c|c|r|}
\hline Pasar & $\begin{array}{c}\text { Jumlah } \\
\text { Los }\end{array}$ & $\begin{array}{c}\text { Tarif } \\
(\mathrm{Rp})\end{array}$ & $\begin{array}{c}\text { Frekuensi } \\
\text { Bayar }\end{array}$ & $\begin{array}{c}\text { Jumlah } \\
(\mathrm{Rp})\end{array}$ \\
\hline Youtefa & 1,229 & 725 & 360 & $320,769,000$ \\
\hline Hamadi & 801 & 725 & 360 & $209,061,000$ \\
\hline Tanjung Ria Dok IX & 280 & 725 & 360 & $73,080,000$ \\
\hline Jumlah & 2,310 & & & $602,910,000$ \\
\hline
\end{tabular}

Sumber : data diolah tahun 2014

Berdasarkan hasil analisis potensi diketahui bahwa untuk Pasar Youtefa potensi penerimaan retribusi berdasarkan fasilitas Los diperoleh nilai sebesar Rp. 320.769.000,- . yang berasal dari 1229 Los yang ada. Untuk Pasar Hamadi potensi penerimaan dari faslitas Los adalah Rp. 209.061.000,- dengan fasilitas los sebanyak 801 unit. Untuk Pasar Tanjung Ria Dok IX potensi penerimaannya adalah Rp. 73.080.000,-. Dari 280 unit Los. Dengan demikian potensi penerimaan retribusi pelayanan pasar dari fasilitas Los di Kota Jayapura adalah Rp. 602.910.000,- dalam satu tahun. Seperti halnya potensi fasilitas kios maka potensi penerimaan dari fasilitas Los ini dapat diperoleh, dengan syarat aktivitas pasar dapat berjalan dengan baik dan pemungutannya dapat dilakukan juga dengan baik.

\section{c. Potensi Retribusi Pelataran}

Adapun tarif yang dikenakan untuk Pasar Kelas II untuk fasilitas Pelataran $1 \mathrm{~m} \times 1 \mathrm{~m}=$ Rp. 300/hari. Adapun padagang yang menggunakan fasilitas pelataran ini adalah para pedagang yang tidak 
menempati kios maupun los, dimana dagangan mereka hamparkan di atas pelataran, menggunakan meja atau menggunakan gerobak. Pada dasarnya pedagang ini masuk dalam kategori Pedagang kaki Lima (PKL). Berdasarkan pengamatan rata-rata pedagang di pelataran menggunakan area $2 \mathrm{~m} \times 1 \mathrm{~m}$, sehingga tarif yang digunakan untuk menghitung potensi disesuaikan dengan kondisi tersebut yaitu $2 \times 1 \times$ Rp300,- = Rp. 600,-/pedagang.

Tabel 4.

Potensi Retribusi Pelayanan Pasar dari Fasilitas Pelataran Kota Jayapura Tahun 2014

\begin{tabular}{|l|c|c|c|c|}
\hline \multicolumn{1}{|c|}{ Pasar } & $\begin{array}{c}\text { Jumlah } \\
\text { Pelataran }\end{array}$ & $\begin{array}{c}\text { Tarif } \\
(\text { Rp) }\end{array}$ & $\begin{array}{c}\text { Frekuensi } \\
\text { Bayar }\end{array}$ & $\begin{array}{c}\text { Jumlah } \\
(\text { Rp })\end{array}$ \\
\hline Youtefa & 842 & 600 & 360 & $181,872,000$ \\
\hline Hamadi & 457 & 600 & 360 & $98,712,000$ \\
\hline Tanjung Ria Dok IX & 108 & 600 & 360 & $23,328,000$ \\
\hline Jumlah & 1,407 & & & $303,912,000$ \\
\hline
\end{tabular}

Sumber : data diolah tahun 2014

Berdasarkan informasi yang diberikan Kepala pasar serta observasi manunjukkan bahwa untuk Pasar Youtefa rata- rata pedagang yang memanfaatkan pelataran adalah 842 orang sehingga potensi penerimaan retribusi berdasarkan penggunaan fasilitas pelataran diperoleh nilai sebesar Rp. 181.872.000,- yang berasal dari 842 pedagang.

Sebagaimana di pasar Youtefa maka informasi dari Kepala Pasar Hamadi dan hasil observasi menunjukkan bahwa rata-rata pedagang yang memanfaatkan pelataran sebanyak 457 pedagang/hari, sehingga potensi penerimaan dari penggunaan faslitas pelataran sebesar Rp. 98.712.000,- . 
Pasar Tanjung Ria Dok IX penggunaan fasilitas pelataran yang ada berdasarkan informasi kepala pasar dan observasi yang dilakukan diketahui sebanyak 108 pedagang/hari. Dengan demikian potensi penerimaan retriusi pasar dari penggunaan fasiliatas pelataran di Pasar Tanjung Ria Dok IX adalah Rp. 23.32.000,-/tahun.

Berdasarkan perhitungan potensi dari ketiga pasar tersebut maka potensi penerimaan retribusi pelayanan pasar dari penggunaan fasilitas pelataran di Kota Jayapura pada tahun 2014 adalah Rp. 303.912.000,- dalam satu tahun. Seperti halnya potensi penerimaan dari fasilitas kios dan Los maka potensi penerimaan dari fasilitas pelataran ini dapat diperoleh.

Berdasarkan hasil perhitungan potensi dari penggunaan fasiltas Kios, Los dan Pelataran dari Pasar Youtefa, Pasar Hamadi dan Pasar Tanjung Ria Dok IX, maka diperoleh bahwa untuk:

a. Pasar Youtefa potensi retribusi pelayanan pasarnya adalah Rp.2.200.401.000,-/tahun.

b. Pasar Hamadi potensi retribusi pelayanan pasarnya adalah Rp.1.522.773.000,-/tahun.

c. Pasar Tanjung Ria Dok IX potensi retribusi pelayanan pasarnya adalah Rp.365.328.000,-/tahun.

Sehingga secara keseluruhan potensi penerimaan PAD dari Aset daerah berupa Pasar di Kota Jayapura berdasarkan jumlah fasilitas yang ada adalah Rp. 4.088.502.000/tahun.

Dari gambaran potensi retribusi pasar ini terlihat bahwa realisasi retribusi pasar di Kota Jayapura selama ini masih jauh dari potensi yang seharusnya dapat diperoleh. Hal ini ditunjukkan oleh realisasi retribusi pasar tertinggi adalah tahun 2013 sebesar Rp.788.927.500,- yang 
berarti pada tahun 2013 tingkat efektifitas penerimaan retribusi pasar baru mencapai 19,29\%. (efektifitas = realisasi $/$ potensi $\times 100 \%$ ).

\section{Potensi Retribusi Terminal}

Retribusi Terminal merupakan jenis retribusi yang masuk dalam kelompok retribusi jasa usaha dan berdasarkan Peraturan Daerah Kota Jayapura Nomor 3 tahun 2012 tentang Retribusi Jasa Usaha Bab IV tentang Retribusi terminal maka setiap penggunaan fasilitas terminal dalam hal ini penyediaan tempat parkir untuk kendaraan penumpang dan bis umum dikenakan pungutan retribusi. Berdasarkan regulasi inilah maka aset daerah dalam bentuk terminal merupakan salah satu sumber penerimaan PAD.

Tabel 5.

Potensi Retribusi Terminal di Kota Jayapura Tahun 2014

\begin{tabular}{|c|c|c|c|c|c|c|}
\hline \multirow[b]{2}{*}{ Terminal } & \multirow[b]{2}{*}{ Jenis Kendaraan } & \multirow[b]{2}{*}{$\begin{array}{l}\text { Jumlah } \\
\text { Kendaraan }\end{array}$} & \multirow[b]{2}{*}{$\begin{array}{l}\text { Tarif } \\
(\mathrm{Rp})\end{array}$} & \multicolumn{2}{|c|}{ Frekuensi Bayar } & \multirow[b]{2}{*}{ Jumlah (Rp) } \\
\hline & & & & $\begin{array}{l}\text { rata- } \\
\text { rata/hari }\end{array}$ & 1 tahun & \\
\hline \multirow{2}{*}{ Youtefa } & Minibis/Starwagon & 266 & 700 & 4 & 1440 & $268,128,000$ \\
\hline & minibis/Cary & 967 & 500 & 6 & 2160 & $1,044,360,000$ \\
\hline Jumlah & & & & & & $1,312,488,000$ \\
\hline
\end{tabular}

Sumber : data diolah tahun 2014

Adapun tarif yang dikenakan berdasarkan Perda. No. 3 tahun 2012 angkutan kota untuk :

a. Mobil penumpang 8 orang tarifnya Rp.500,;/sekali masuk

b. Bis kecil tarifnya Rp.700.,-/sekali masuk

Adapun mobil penumpang 8 orang merupakan kendaraan angkutan kota yang lebih dikenal dengan dengan istilah cary, sedangkan minibis merupakan angkutan penumpang yang lebih dari 8 s/d 12 orang dan lebih dikenal dengan istilah starwagon. 
Berdasarkan hasil perhitungan terlihat bahwa untuk minibis (starwagon) dengan jumlah kendaraan sebanyak 266 dan rata-rata masuk terminal 4 kali/hari maka potensi penerimaan retribusinya adalah Rp.268.128.000,-/tahun.

Untuk mobil penumpang 8 orang (cary) dengan jumlah kendaraan 967 unit dan rata-rata masuk terminal youtefa sebanyak 6 kali/hari, maka potensi penerimaan retribusinya adalah Rp.1.044.360.000,-.

Sehingga secara keseluruhan potensi retribusi yang diperoleh dari retribusi terminal adalah Rp.1.312.488.000,-, melihat potensi retribusi terminal ini maka realisasi retribusi terminal tertinggi yang telah dicapai selama ini yaitu pada tahun 2009 sebesar Rp. 430,505,000,bukan merupakan tingkat yang optimal, karena jika dilihat dilihat maka masih terdapat selisih potensi yang belum dapat di peroleh Pemerintah Kota Jayapura yaitu sebesar Rp.881.983.000,-. Bahkan jika dibandingkan dengan capain realisasi retribusi terminal tahun 2013 yang nilainya sebesar Rp.244.706.000,- maka selisih realisasi penerimaan dengan potensi yang belum dapat diperoleh sebesar Rp.1.067.782.000,-

Adapun potensi penerimaan PAD Pemerintah Kota Jayapura yang dihitung berdasarkan potensi retribusi pelayanan pasar dan potensi retribusi terminal menunjukkan bahwa nilai penerimaan yang dapat diperoleh sebesar Rp. 5.400.990.000,-. Nilai potensi ini masih sangat jauh jika dibandingkan dengan realisasi penerimaan PAD tertinggi yang berasal dari aset daerah (terminal dan pasar) yaitu pada tahun 2013 sebesar Rp. 1.033.633.500,- sehingga masih terdapat potensi retribusi pasar dan terminal sebesar Rp4.367.356.500,- yang belum dapat diperoleh pemerintah daerah Kota Jayapura. 


\section{Efektifitas Penerimaan Retribusi Pasar dan Retribusi Terminal.}

Realisasi Penerimaan retribusi Pasar dan Terminal jika dilihat dari sisi nilai potensi penerimaan menunjukkan angka yang relative besar, namun jika dibandingkan dengan realisasi capainnya menunjukkan masih jauh dari yang seharusnya dapat diperoleh. Kondisi ini tentunya memberikan gambaran bahwa aktivitas pemungutan retribusi baik pasar maupun terminal belum berjalan dengan optimal bahkan dapat dikatakan masih sangat jauh dari kondisi ideal yang seharusnya dapat dilakukan. Untuk melihat kondisi ini maka dilakukan dengan melihat bagaimana tingkat efektifitas pencapaian penerimaan retribusi baik retribusi pasar maupun retribusi terminal melalui perbandingan antara potensi penerimaan retribusi dan realisasi penerimaan retribusi.

Tabel 6.

Efektifitas Penerimaan Retribusi Pasar dan Retrubusi Terminal Kota Jayapura Tahun 2013

\begin{tabular}{|l|r|r|c|}
\hline \multirow{2}{*}{$\begin{array}{c}\text { Jenis } \\
\text { Retribusi }\end{array}$} & \multicolumn{3}{|c|}{ Nilai Retribusi } \\
\cline { 2 - 4 } & Realisasi (Rp) & Potensi (Rp) & $\begin{array}{c}\text { Efektivitas } \\
(\%)\end{array}$ \\
\hline Pasar & $788,927,500$ & $4,088,502,000$ & 19.30 \\
\hline Terminal & $244,706,000$ & $1,312,488,000$ & 18.64 \\
\hline Total & $1,033,633,500$ & $5,400,990,000$ & 19.14 \\
\hline
\end{tabular}

Sumber: Data diolah 2014

Hasil perhitungan efektifitas maka dapat dilihat bahwa untuk retribusi pasar dengan nilai realisasi penerimaan retribusi Pasar sebesar Rp. 788.927.500,- pada tahun 2013, sedangkan potensi penerimaan retribusi pasar jika dapat berjalan dengan optimal baik kondisi pasar dan pemungutannya maka nilai potensi yang dapat diterima sebesar 
Rp.4.088.502.000,- maka efektifitas dari penerimaan retribusi pasar pada tahun 2013 baru mencapai 19,30\%. Dengan kondisi nilai efektiftas sebesar $19,30 \%$ maka efektifitasnya berada pada ketegori sangat tidak efektif .

Hal ini tentunya menunjukkan bahwa penerimaan retribusi yang selama ini dicapai terutama tahun 2013 masih belum mampu mecapai tingkat yang optimal karena masih ada $80,70 \%$ potensi penerimaan yang belum dapat dipungut. Kondisi ini tentunya menunjukkan masih banyak berbagai factor yang menyebabkan penerimaan retribusi pasar masih belum efektif, yang mungkin saja diakibatkan oleh; seperti kurang berfungsinya semau fasilitas pasar, pelaksanaan pemungutan yang kurang tepat dan lain sebagainya.

Terminal sebagai salah satu bagian dari Aset daerah juga memberikan pendapatan pada pemerintah Kota Jayapura melalui penerimaan retribusi terminal, yang merupakan bentuk pelayanan pada masyarakat melalui fasilitas terminal.

Hasil perhitungan efektifitas terlihat bahwa bahwa retribusi terminal dengan nilai realisasi penerimaan retriusi terminal sebesar Rp. 244.706.000,- pada tahun 2013, maka jika dibandingkan dengan potensi penerimaan retribusi terminal, apabila dapat dijalankan dengan baik maka nilai potensi yang dapat diterima sebesar Rp.1.312.488.000,- terlihat masih jauh dari yang seharusnya. Hasil perhitungan efektifitas penerimaan retribusi terminal pada tahun 2013 menunjukkan angka 18,64\%. Yang berarti tingkat efektifitasnya berada pada kategori sangat tidak efektif.

Hal ini tentunya memberikan gambaran bahwa penerimaan retribusi yang dicapai pada tahun 2013 masih belum mampu mecapai tingkat yang optimal karena masih ada $81,36 \%$ penerimaan retribusi 
terminal dalam bentuk potensi yang belum dapat dipungut. Sebagaimana retribusi pasar maka kondisi retribusi terminal juga menunjukkan masih banyak faktor yang perlu diperhatikan dan dimaksimalkan guna meningkatkan capaian penerimaan retribusi terminal di Kota Jayapura.

Jika dilihat secara keseluruhan dalam jumlah total baik retribusi pasar maupun retribusi terminal maka terlihat bahwa nilai efektifitas penerimaan retribusi baru mencapai $19,14 \%$, yang berarti masih terdapat $80,86 \%$ penerimaan retribusi dari pasar dan terminal yang belum dimaksimal. Tentunya hal ini sangat disayankan, karena retribusi daerah sebgai sumber penerimaan PAD merupakan salah satu komponen yang menunjang pembiayaan pembangunan, bahkan peningkatan PAD tentunya akan meningkatkan kemampuan fiscal daerah.

\section{Upaya-upaya yang dilakukan guna meningkatkan penerimaan Retribusi Pasar dan Terminal di Kota Jayapura}

Potensi penerimaan PAD dari Aset daerah yang ada belum mampu dimanfaatkan dengan optimal hal ini. Hasil dari wawancara dengan kepala Pasar Hamadi, Youtefa dan Tanjung Ria Dok IX serta kepala Terminal Youtefa mengenai berbagai faktor yang menyebabkan belum optimalnya realisasi penerimaan retribusi pasar dan dan terminal untuk itu dikemukakan faktor penyebab dan upaya yang dapat dilakukan yaitu:

\section{Pasar Tanjung Ria Dok IX}

a. Faktor penyebab tidak optimal

1) Masih ada fasilitas pasar yang tidak difungsikan sebagaimana mestinya oleh pemilik fasilitas terutama fasilitas kios. 
2) Masih terdapat pengguna fasilitas pasar terutama los dan pelataran yang membayar tidak sesuai dengan fasilitas yang digunakan.

3) Masih adanya petugas pemungut baik retribusi pasar yang melakukan pungutan tanpa memberikan karcis.

b. Upaya-Upaya

1) Melakukan pendataan terhadap fasilitas yang yang ada dengan lebih baik.

2) Penagihan dilakukan dengan mendasarkan pada kondisi fasilitas yang digunakan sesuai dengan hasil pendataan.

3) Memberikan bekal moral pada setiap petugas secara berkala.

\section{Pasar Hamadi}

a. Faktor penyebab tidak optimal

1) Masih ada fasilitas pasar yang tidak difungsikan sebagaimana mestinya oleh pemilik fasilitas terutama fasilitas kios.

2) Masih terdapat pengguna fasilitas pasar terutama los dan pelataran yang membayar tidak sesuai dengan fasilitas yang digunakan.

3) Masih adanya petugas pemungut baik retribusi pasar yang melakukan pungutan tanpa memberikan karcis.

4) Adanya Klaim pemilikan tanah ulayat oleh pihak masyarakat adat, sehingga petugas tidak dapat maksimal melakukan pemungutan retribusi.

b. Upaya-Upaya 
1) Melakukan pendataan terhadap fasilitas yang yang ada dengan lebih baik

2) Penagihan dilakukan dengan mendasarkan pada kondisi fasilitas yang digunakan sesuai dengan hasil pendataan.

3) .Memberika bekal moral pada setiap petugas secara berkala.

4) Melakukan pendekatan pada pihak masyarakat adat guna memaksimalkan fasilitas yang telah dibangun.

5) Melakukakan penegakan hukum dalam hubungannya dengan pemilikan tanah melalui pengadilan.

\section{Pasar Youtefa}

a. Faktor penyebab tidak optimal

1) Masih ada fasilitas pasar yang tidak difungsikan sebagaimana mestinya oleh pemilik fasilitas terutama fasilitas kios.

2) Masih terdapat pengguna fasilitas pasar terutama los dan pelataran yang membayar tidak sesuai dengan fasilitas yang digunakan.

3) Masih adanya petugas pemungut baik retribusi pasar yang melakukan pungutan tanpa memberikan karcis.

4) Kondisi Pasar Youtefa dan yang rawan banjir, menyebabkan pada saat-saat tertentu tidak dapat berfungsi dengan baik.

b. Upaya-Upaya

1) Melakukan pendataan terhadap fasilitas yang yang ada dengan lebih baik

2) Penagihan dilakukan dengan mendasarkan pada kondisi fasilitas yang digunakan sesuai dengan hasil pendataan. 
3) Memberika bekal moral pada setiap petugas secara berkala.

4) Melakukan perbaikan terhadap fasilitas yang rusak

5) Memperbaiki daya dukung lingkungan sehingga pasar dapat terhindar dari banjir musiman.

\section{Terminal Youtefa}

a. Faktor -faktor penghambat

1) Kondisi Terminal Youtefa yang kurang memadai (banyak genangan air dan fasilitas jalan yang buruk) menyebabkan tidak semua angkutan umum penumpang mau masuk ke terminal yotefa.

2) Masih adanya petugas pemungut baik retribusi terminal yang melakukan pungutan tanpa memberikan karcis.

b. Upaya-upaya perbaikan

1) Melakukan perbaikan tehadap fasilitas terminal maupun akses jalan masuk dan keluar, sehingga masyarakat pengguna terminal dapat merasa nyaman.

2) Melakukan pembinaan terhadap petugas pemungut retribusi dalam hal mental dan spiritual secara berkala.

Jika dicermati secara menyeluruh dan mendalam maka berbagai faktror penyebab tidak tercapainya penerimaan retribusi yang optimal dan upaya-upaya yang perlu dilakukan adalah sebagai berikut.

Faktor-faktor penyebab tidak optimalnya penerimaan retribusi pasar dan terminal adalah :

1 Masih terdapat pengguna fasilitas pasar terutama los dan pelataran yang membayar tidak sesuai dengan fasilitas yang digunakan. 
2 Kondisi Terminal Youtefa yang kurang memadai (banyak genangan air dan fasilitas jalan yang buruk) menyebabkan tidak semua angkutan umum penumpang mau masuk ke terminal yotefa.

3 Masih adanya petugas pemungut baik retribusi pasar maupun terminal yang melakukan pungutan tanpa memberikan karcis.

4 Masih adanya permasalahan hukum terhadap pemilikan tanah dimana fasilitas pemerintah tersebut berada.

Berdasarkan hal-hal tersebut diatas maka pemerintah daerah Kota Jayapura perlu melakukan upaya-upaya dalam pengelolaan/memanfaatkan sumber-sumber penerimaan retribusi pasar dan terminal dengan lebih baik. Adapun upaya-upaya guna meningkatkan penerimaan Pendapatan Asli Daerah dari aset daerahadalah sebagai berikut :

1. Meningkatkan kualitas aparat/petugas pemungut; Peningkatan kualitas petugas dapat dilakukan melalui pembekalan tentang moral dan etika guna mendorong pengawasan melekat dalam diri petugas pemungut sehingga mereka tidak melakukan penyimpangan dalam aktivitasnya. Selain itu perlu ada peningkatan kesejahteraan bagi petugas penarik retribusi pasar dan terminal guna mengurangi terjadinya penyimpangan dalam melaksanakan tugasnya yaitu melakukan pemungutan retibusi baik retribusi pasar maupun terminal, hal ini disebabkan pendapatan pemungut retribusi pasar dan terminal yang relatif kecil.

2. Perbaikan sistem administrasi dan prosedur kerja; Upaya - upaya yang perlu dilakukan dalam perbaikan sistem administrasi yaitu melakukan pendataan fasilitas pasar dan terminal (yang telah dimanfaatkan maupun yang belum dimanfaatkan baik kios dan los dan pelataran serta kondisi terminal dan fasilitas jalannya) Selain itu perlu adanya prosedur kerja yang jelas bagi pemungut retribusi pasar dan terminal, terutama mengenai tanda pengenal dan seragam bagi 
pemungut dalam melaksanakan tugasnya, sehingga wajib retribusi dapat mengetahui pemungut retribusi resmi dan yang tidak resmi.

3. Perbaikan fasilitas Pasar dan terminal serta lingkunganya; Perlu dilakukan perbaikan fasilitas pasar dan terminal yang tidak layak baik fasilitas kios, los dan pelataran, lapangan terminal dan akses jalannya.

4. Perlu mengambil tindakan yang tegas: tindakan ini baik berupa sanksi administrasi maupun melalui penegakan hukum kepada masyarakat pengguna fasilitas pasar dan terminal yang tidak bersedia membayar retribusi yang tidak sesuai dengan ketentuan yang berlaku.

5. Melakukan penyelesaian hukum atas pemilikan tanah dimana fasilitas pasar tersebut berada.

\section{KESIMPULAN DAN SARAN}

\section{Kesimpulan}

Berdasarkan hasil analisis potensi penerimaan Retribusi Pasar dan

Terminal di Kota Jayapurayang, maka kesimpulan yang dapat dikemukakan adalah :

a. Potensi penerimaan dari Retribusi Pasar dan Terminal lebih tinggi dari realisasi penerimaan tertinggi yang pernah dicapai, dimana potensinya sebesar Rp.5.400.990.00,-. Sedangkan realisasi hanya Rp.1.033.633.500,--

b. Efektifitas penerimaan retribusi pasar dan terminal belum mencapai tingkat yang maksimal dimana secara keseluruhan maka efektifitasnya baru mencapai angka 19,14\% yang berarti sangat tidak efektif . Sedangkan efektifitas penerimaan retribusi pasar baru mencapai angka 19, 30\% yang berarti sangat tidak efektif dan efektifitas penerimaan retribusi terminal baru mencapai angka $18,64 \%$. yang berarti sangat tidak efektif. 
c. Upaya-upaya yang harus dilakukan adalah :a) Meningkatkan kualitas aparat/petugas pemungut; b) Perbaikan sistem administrasi dan prosedur kerja, c) Perbaikan fasilitas Pasar dan terminal serta lingkunganya; d) Perlu mengambil tindakan yang tegas: e) Melakukan penyelesaian hukum atas pemilikan tanah dimana fasilitas pasar berada.

\section{Saran}

a. Pemerintah Kota Jayapura melalui Dinas Pendapatan Daerah dalam menetapkan target penerimaan retribusi pasar dan terminal diharapkan mempertimbangkan pada potensi riil yang dimiliki.

b. Perlu ditingkatkan kemampuan dan semangat aparatur pengelola sumber - sumber penerimaan sehingga mampu meningkatkan kinerja dan memberi kontribusi yang nyata peningkatan penerimaan daerah.

c. Terus menerus meningkatkan kesadaran masyarakat pengguna fasilitas pasar dan terminal melalui sosialisasi dan pengarahan yang dapat mendorong masyarakat menyadari dan melaksanakan kewajibannya.

d. Guna lebih mengoptimalkan Penerimaan Daerah yang berasal dari penerimaan retribusi pasar dan terminal, perlu peningkatan pelayanan kepada pedagang dalam bentuk perbaikkan fasilitas pasar dan penataan ulang penggunaan fasilitas pasar.

e. Penertiban pemungutan retribusi pasar dengan mengurangi kemungkinan pemungutan tidak sesuai dengan peraturan yang berlaku.

f. Penarikan / pemungutan retribusi pasar tetap harus dilakukan oleh petugas dengan tanda pengenal walaupun pada hari libur atau hari Minggu

g. Pendataan kembali kepemilikan fasilitas pasar khususnya kios 
yang tidak difungsikan sebagaimana mestinya dialihkan kepemilikannya kepada yang benar-benar membutuhkan fasilitas tersebut.

\section{DAFTAR PUSTAKA}

Abdul Halim, Ibnu Subiyanto, 2008. Analisis Investasi (Belanja Modal) Sektor Publik-Pemerintah Daerah, Penerbit UPP STIM YKPN, Yogyakarta

, M. lqbal, 2012. Pengelolaan Keuangan Daerah, Penerbit UPP STIM YKPN, Yogyakarta

Empat,Jakarta

, 2012. Akuntansi Sektor Publik,Penerbit Salemba

Agus Sartono, manajemen Keuangan, Penerbit BPFE Yogyakarta

Chabib Soleh,Heru Rochmansjah, 2009. Pengelolaan Keuangan Dan Aset Daerah,Penerbit Fokusmedia,Bandung

, Suripto, 2011. Menilai Kinerja Pemerintah Daerah,Penerbit Fokusmedia,Bandung

Doli D. Siregar, 2004. Manajemen Aset Strategi Penataan Konsep Pembangunan Berkelanjutan Secara Nasional Dalam Konteks Kepala Daerah Sebagai CEO's Pada Era Globalisasi \& Otonomi Daerah, Penerbit PT. Gramedia Pustaka, Jakarta

Herri Waloejo, 2011. Penggunaan Dan Pemanfaatan Barang Milik Negara (suatu Perbandingan Kebijakan Sebelum Dan Sesudah Reformasi Keuangan Negara), Penerbit Mitra Wacana Media

Irwan Taufiq Ritonga, 2012. Perencanaan Dan Penganggaran Keuangan Daerah Di Indonesia, Penerbit Lembaga Kajian Manajemen Pemerintah Daerah, Yogyakarta

Juli Panglima Saragih, 2003. Desentralisasi Fiskal Dan Keuangan Daerah Dalam Otonomi,Penerbit Ghalia Indonesia,Jakarta

Lincolin Arsyad, Pengantar Perencanaan Pembangunan Ekonomi Daerah, Yogyakarta

M.Yusuf,2010. Delapan Langkah Pengelolaan Aset Daerah Menuju Pengelolaan Keuangan Daerah Terbaik,Penerbit Salemba Empat 
Marihot Pahala Siahaan, SE, MT, 2008. Pajak Daerah \& Retribusi Daerah Berdasarkan Undang-Undang Nomor 28 Tahun 2009 Tentang Pajak Daerah Dan Retribusi Daerah, Penerbit PT.RajaGrafindo Persada,Jakarta

Menase Robert Kambu, M.Si,DKK, 2009. Prospek PAD Kota Jayapura Pasca Otonomi Khusus, Penerbit PT. Indomedia Global, Jakarta, Yogyakarta

Mohamad Khusaini, SE, M.Si, MA, Disentralisasi Fiskal Dan Pembangunan Daerah, Penerbit BPFE Unibraw

Pemerintah Republik Indonesia. 2000. Keppres 17 Tahun 2000 Tentang Pelaksanaan Anggaran Pendapatan Dan Belanja Negara Serta Keppres 18 Tahun 2000 Tentang Pelaksanaan Pengadaan Barang/Jasa Instansi Pemerintah,Penerbit CV. Catur Utama, Jakarta

Indonesia Nomor 58 Tahun 2005 Tentang Pengelolaan Keuangan Daerah, Badan Pendidikan Dan Pelatihan Departemen Dalam Negeri

2006a. Departemen Dalam Negeri Republik Indonesia Peraturan Menteri Dalam Negeri Nomor 59 Tahun 2007 Tentang Perubahan Atas Peraturan Menteri Dalam Negeri Nomor 13 Tahun 2006 Tentang Pedoman Pengelolaan Keuangan Daerah, Direktorat Jenderal Bina Administrasi Keuangan Daerah

. 2006b. Peraturan Pemerintah Republik Indonesia Nomor 6 Tahun 2006 tentang Pengelolaan Barang Negara/Daerah, Penerbit CV. Eko Jaya, Jakarta

. 2007a. Peraturan Menteri Dalam Negeri Nomor 17 Tahun 2007 Tentang Pedoman Teknis Pengelolaan Barang Milik Daerah, Direktorat Jenderal Bina Administrasi Keuangan Daerah Departemen Dalam Negeri

. 2007b. Peraturan Menteri Dalam Negeri Nomor 17 Tahun 2007 Tentang Pedoman Teknis Pengelolaan Barang Milik Daerah, Penerbit Nusantara . 2012a. Peraturan Daerah Kota Jayapura nomor 2 tahun 2012 tentang Retribusi Jasa Umum 2012b. Peraturan Daerah Kota Jayapura nomor 3 tahun 2012 tentang Retribusi Jasa Usaha. 
Sartiwi Ramba, 2010. analisis Potensi Retribusi Pasar di Kabupaten Nabire, Tesis Magister Ilmu Ekonomi FE-Uncen (tidak dipublikasikan)

Sugiyono, 2013. MetodePenelitian Kuantitatif, Kualitatif Dan R\&D, Penerbit Alfabeta,Bandung

Surya Dharma, 2005. Manajemen Kinerja,Penerbit Pustaka Pelajar,Yogyakarta

Untung Supardi, ADV.DEM, M.Si, Heri Basuki Rudianto,SH,MT, Mohammad Luthfi Amirul Mukminin, SE, MT, Penilaian Dan Properti, Penerbit Mitra Wacana Media

Yayat Hayati Djatmiko,2008. Perilaku Organisasi, Penerbit Alfabeta, Bandung 